\title{
China's Evolution from Socialist Legality: The Expansion in the Role of Judges and the Redress of Grievances
}

\author{
Zia Akhtar ${ }^{1}$ \\ ${ }^{1}$ LLB (Lon) LLM (Lon) Gray's Inn, UK \\ Correspondence: Zia Akhtar, LLB (Lon) LLM (Lon) Gray's Inn, UK. E-mail: pcgraduate@googlemail.com
}

Received: November 5, 2021

Accepted: December 17, 2021

Online Published: December 24, 2021

doi:10.5539/jpl.v15n1p52

URL: https://doi.org/10.5539/jpl.v15n1p52

\begin{abstract}
The Chinese state implemented a conscious transfer to a market economy after 1977 when the Four Modernisations were inaugurated and the new Constitution promulgated in 1982 raised the possibility for the separation of powers. The new framework introduced judicial review into the structure of the legal system that was to provide redress of grievances from mal administration. The transition to a new leadership in 2011 allowed the National Peoples Congress to enact administrative reforms, and further amendments to the Chinese Constitution in 2018 have promulgated the Judges Law. The judicial reforms promote the values of an independent judiciary and there is an effective machinery of justice which promotes judicial review. This paper argues that the centralisation of power by the Communist Party does not preclude the functioning of judicial administration that conforms to rule of law and an emerging trend of public interest litigation and participatory justice.
\end{abstract}

Keywords: confucius, li, judicial review, property law, environmental protection law, legalist philosophy, administration of justice, judges law

\section{Introduction}

The Peoples Republic of China (PRC) proclaimed a Socialist state after Mao Tse Tung in 1949 which brought the Communist Party into power. Its regeneration by the Cultural Revolution led to the Maoist strand of Communism and the interpretation of Marxism Leninism in the Chinese framework. After the fall of the 'Gang of Four' in 1977 the Deng Xiaoping led reforms' inaugurated the era of the four modernisations. This is when China advanced towards its own version of a rule of law and since the Constitutional amendment of 2018 there is an expansion of the judicial branch and an increase in the administration powers of the courts. The issue is the extent to which the judicial reforms promote the separation of powers and allow the function of judicial review.

The PRC came into existence in 1949 and has had four constitutions which were adopted in 1954, 1975, 1978 and 1982 with revisions in 1988, 1993,1999, 2004 and 2018. The judiciary in China was established under Articles 123-135 of the 1982 Constitution and the structure of the courts is represented by a hierarchy of 'peoples' courts that leads to the Peoples Supreme Court at the apex of its judicial system. ${ }^{1}$ The remaining three levels are Higher People's Courts, the Intermediate People's Courts and the Basic Peoples Courts. Throughout the system, litigants are generally limited to one appeal, on the theory of finality of judgment by two trials. The appeals are often reviewed de novo as to both law and facts. ${ }^{2}$

The Chinese state has adopted the organic theory of Marxism that is the moving spirit of its political constitution which by recourse to the doctrine of "revolutionary legality" is based on class consciousness and the replacement of the bourgeoisie by the proletariat. The political party system in China defines itself as a "multi-party cooperation system with political consultation under the leadership of the Communist Party of China (CCP) which is different from both the two-party or multi-party competition systems of Western countries and the one-party

\footnotetext{
${ }^{1}$ According to the Constitution and the Organic Law of the People's Courts of 1979 as amended in 1983, China practices a system of courts characterized by " four levels and two instance of trials". The judicial authority of the PRC is exercised by the following people's courts: local people's courts at various levels; military courts and other special people's courts and the Supreme People's Courts. China's Judicial System: Peoples Courts, Procuratorates and Public Security. https://olemiss.edu/courses/pol324/chnjudic.htm accessed 15February 2020

${ }^{2}$ Rongxing Guo, How the Chinese Economy Works, Palgrave Macmillan, (2016) p 136
} 
system practiced in some other countries". ${ }^{3}$ The overbearing nature of the CCP has been viewed as a possible obstacle to the functioning of the judicial review process.

In determining the progress made by China towards the administration of justice by the courts it is necessary to evaluate its contemporary legal dispensation. While the Chinese framework has an operational de jure code of law there is a moral code that allows people to have a sense of self regulation which stems from the philosopher of antiquity Confucius whose logic was the integration of the citizens to solve the myriad problems of society. ${ }^{4}$ Confucius's theory is that the state acts as parent through its moral guardianship and although legislation in China differs from the epistemology of Taoisim, Confuciusanism, and Legalism these principles underpin Chinese political and legal theory. ${ }^{5}$

While the Confucian ideology of personal and social morality was for 2000 years the natural law adapted by Chinese rulers the current government prefers the Legalist philosophy. ${ }^{6}$ The new dispensation that came into effect after 1949 provided a platform for China to reformulate the human resource to "acquire the correct proletarian attitudes", stretching back to Confucius for whom the "chief virtue" was "humaneness". This was the valid solution to resolving disputes even if the communist theory had "little room for religion"7 and was the basis for a material foundations of the Marxist Leninist dictatorship of the proletariat that Mao wanted to emulate in the PRC. ${ }^{8}$

This paper addresses the role of the machinery of justice of China and how it has transformed in since the 1982 Constitution and has enabled the rule of law to develop in the PRC. Part A considers the theory of the state as parent and custom as the source of norms; Part B evaluates the rule of law and administrative litigation; Part C defines the public interest litigation, the new model of participatory justice, and the judicial review; Part D examines the independent judiciary and oversight of legislation; Part $E$ evaluates the role of the party and extension of judicial branch in the Chinese constitution; and Part F concerns the Judges law and prospects of judicial review process by the constitutional amendments. This will provide an insight into the development of the rule of law, the separation of powers, the role of the CCP that has traditionally determined the overarching power of the executive. It will explore how the innovation of the Judges Law will increase judicial review by the expansion and professionalism of the judicial branch.

\section{Customary Law and State as Parent}

In China the ancient repository of political wisdom and custom was sourced to the philosophy of Confucius whose treatise consists of a collection of "brief aphoristic fragments" that for nearly 2,000 years were part of the ethos of the Chinese people. These ethical foundations of state relied on the idea that human beings are fundamentally good in nature and ought to be treated humanely. Confucius espoused $l i-$ a traditional norm, which can be interpreted as " propriety, ethics, or moral rules of correct conduct and good manners" that regulates the 'five relations': ruler and subject, father and son, husband and wife, elder and younger brother, and friend". 9 This is to advance the requirement of harmony in the social universe that approximates to a natural order that serves as a moral imperative. ${ }^{10}$ This is contrasted with $f a$ which is another principle of government that regulates the community.

In the Analects of Confucius $1 i$ is a form of social control whose most significant dependent virtues " are gong 恭 and jing 敬. Both terms pertain to expression of respect for others. For distinguishing gong from jing, we may say that the former pertains primarily to outward appearance, the latter to one's inner attitude". ${ }^{11}$

It is argued that "Gong's principal focus is appearance (rong 容), jing on human affairs. Gong is seen in outward

\footnotetext{
3 White Paper' China's Political Party System, Information Office of the State Council, 15-11-07 http://manchester.chineseconsulate.org/eng/xwdt/t381330.htm

${ }^{4}$ The Analects of Confucius by William Edward Soothill (Yokohama, Fuicken Printing Company, 1910) p 34

5 Ibid 331

${ }^{6}$ Ibid 336

${ }^{7}$ Raymond Dawson, Confucius, (1981) Oxford University Press p 44

${ }^{8}$ The impact of Confucian upon China's contemporary political system and the folk traditions of Chinese statehood is corroborated by the Publicity Department of the CC's projection, "in media addressed to the foreign audience, in order to expand China's soft power and disguise the Leninist nature of the Party". Zhang Weiwei, The China Wave. Rise of a Civilizational State, World Century Publishing, 2012. Also see Mingjun Lu, The Bene-Ideal: China's Cosmopolitan Vision of World Order, Chinese Political Science Review volume 1, (2016) p 336

${ }^{9}$ Luke T. Lee and Whalen W. Lai, The Chinese Conceptions of Law: Confucian, Legalist, and Buddhist, 29 HastingsL.J.1307 (1978) at p 1308. Available at: https://repository.uchastings.edu/hastings_law_journal/vol29/iss6/3

${ }^{10}$ Fan Kun, Arbitration in China. A Legal and Cultural Analysis. Hart Publishing, (2016) Preface

11 Antonio Cua, Virtues of Junzi, Confucian Ethics in Retrospect and Prospect, Edited by Vincent Shen Kwong-loi Shun, Chinese Philosophical Studies, XXVII, Council for Research in Values and Philosophy, p18
} 
expression (wai 外), jing focuses on what is within (zhong 中).”12 This explanation is supported by Confucius's remark that among the nine things that occupy junzi's thought is “to think of appearing respectful (gong 恭) when it comes to demeanor (mao si gong 貌思恭)" and “to think of being reverend when attending to human affairs (shi si jing 事思敬)" ${ }^{13}$ It implies that gong refers to one's behaviour and Jing embodies the virtuous conduct, more relevant to one's inner self belief.

In any conflict between $l i$ and $f a$, traditional Chinese society preferred $l i$. The reason for this observation was elucidated by Confucius:

"If the people are guided by fa, and order among them is enforced by means of punishment, they will try to evade the punishment, but have no sense of shame, but if they are guided by virtue, and order among them is enforced by li, they will have the sense of shame and also be reformed". ${ }^{14}$

Confucius stated that there had to be a value system that should govern the norms of good behaviour: "As a judge, I decide disputes, for that is my duty; but the best thing that could happen would- be to eliminate the causes for litigation."15 In Confucian logic a social order achieved through formal laws does not conform to the ideal of better citizenry. It is manifest that in the absence of any procedural safeguard afforded by codified laws, in the interpretation of $l i$ in which Confucius admonished the ruler to understand that $l i$ is able to create solutions to conflict and problems that the society faces.

This concept sets out the moral code of conduct for the community and it includes participation by the members of the polity and is overriding over $f a$ which appears in the Analects only twice. ${ }^{16}$ It has been described in the oldest philosophical texts in Chinese as the "connotation of law, justice or punishment". ${ }^{17}$ It is the combination of fa li that provides the binding rules in the state and the quality of the rule determines the virtue of the political order. In contrast to the $l i$-based theory, formal legalism advocates the utilization of codified laws and penalties to achieve social order. ${ }^{18}$ As the ruler's judgment often leads to adverse results the legalists have designed a system in which the law is imposed by the state, not the ruler and it is irrelevant whether he has superior abilities. The concept of wuwei 无为, which is drawn from the Confucians" understanding of the same concept invests the ruler with the ultimate authority to decide what the law should be. ${ }^{19}$

The word "law" understood as a uniform framework has four different interpretations in Chinese as in $l i$ ? (“order"), $l i$ 礼 (“rites", "rules of propriety”), $f a$ 法 (“human made laws") and $z h i$ 治 (“control”). ${ }^{20}$ The term which preceded $f a$ was $x i n g$, which originally referred to decapitation, but later evolved to be a general term for laws that relate to criminal punishment. The early criminal justice was enforced through Shang Shu which recorded the original forms of the "five penalties" - Tattooing, disfigurement, castration, mutilation and death. ${ }^{21}$ However, when written law came into existence, the meaning of xing was extended to include not only punishments, but also any state prohibitions whose violation would result in penalties. In this period xing was understood in the sense of penal law or criminal law and there was a criminal law enforcement that translated into the xing bu ("Department of Punishment") which served as the Ministry of justice in imperial China. ${ }^{22}$

This was a period characterized mainly by the concept of law as serving the state, a means of exerting control over the citizenry. In the late Qing dynasty there were efforts to reform the statutes by importing German codes with some modifications when there was clear distinction between law and morality. This was deemed as a conflict between two different concepts of law based on legal principle (fali), the other on moral teachings (lijiao) which

\footnotetext{
${ }^{12}$ Zhu Xi, Sishu jizhu, 四書集註 (Hong Kong: Taipingyang, 1980), p 91.

${ }^{13}$ Analects of Confucius, supra 6 at 16.10

${ }^{14}$ Ibid, Book II, Chapter 3

${ }^{15}$ Ibid, Book II Chapter 4

${ }^{16}$ Books 9.23; 20.1.6.

${ }_{17}$ Jana Benicka, Fa (1) Did its meaning change in Chinese philosophy ? Some remarks on Fa in Confuciusism and Legalism, Asian and African Studies, 10, 2001, 44-55. https://www.sav.sk/?lang=en\&doc=journal-list\&part=article_response_page\&journal_article_no=11226

18 Jerome Cohen and John Lange, The Chinese Legal System, A Primer for Investors, 17 New York Law School of International and Comparative Law, (1997) p 348

19 This is a principle involves knowing when to act and when not to act. Taoism -The Wu Wei Principle Part 4, by Ted Kardash. (June 1998) http://www.jadedragon.com/archives/june98/tao.html; Also see Thomas Michael, Explorations in Authority in the Daodejing: A Daoist Engagement with Hannah Arendt Religions 2018, 9(12), https://doi.org/10.3390/re19120378378

${ }^{20}$ Lang Chippings, (Explicating 'Law': A Comparative Perspective of Chinese and Western Legal Culture)3(1) Journal of Chinese Law (1989) p 55.

${ }^{21}$ Peter K. Yu, The TRIPS Enforcement Dispute, 89 Neb. L. Rev. 1046 (2011). Available at: https://scholarship.law.tamu.edu/facscholar/553

${ }^{22}$ Ibid
} 
was effected by disagreement over the fornication issue that helped to generate awareness of civil law reforms for the Chinese polity. ${ }^{23}$ This effort towards codification emanated from the Provisional Constitution of 1912, until the revolution of 1949 .

The classical interpretation of the Chinese character Fa denotes a meaning of "fair", "straight" and "just", and it also carries the sense of "standard, measurement, and model". ${ }^{24}$ It can be read in the concept of $f a$ with its association with $y i$ ("social rightness". An illustration of the linguistic difference in translation can be deemed from Yan Fu's in his Chinese translation of Baron Louis Montesquieu's 'De lesprit des lois' that was published in 1913, which prepared readers to adopt a western scientific logic. The logic replaced the yin-yang cosmology which was expressed as a metaphysical theory compatible with modern science. ${ }^{25}$

In contemporary China the concept of $l i$ has been institutionalized with the central government adopting norms that provide a mandate to legislate and establish a judicial authority and a bureaucracy to implement the laws and to administer justice. ${ }^{26}$ The issue is, firstly, is to what extent the judiciary in China is able to adopt a proactive role in carrying the judicial review process based upon the review of legislation by the state, and secondly, to adjudicate on the redress of grievances.

\section{Rule of Law and Administrative Litigation}

The CCP, emulated the principles inherent in the Confucian ideology after it ascended into power and the political role of ideology was based on the state acting as parent. It reached its zenith during the Maoist Great Leap Forward in 1958-59 and the Cultural Revolutionary decade from 1966-76. Such movements were in consonance with Mao's aspirations and political thought which put forth the concept of 'mass mobilisation' and 'continuous revolution'. During this period of upheaval the proletariat was the dynamic force of the revolution and the law was to be abolished once the class system was levelled. ${ }^{27}$

However, unlike the long term projection of Marxist writers China has not abolished 'law' once the communist society was established under the auspices of the CCP. ${ }^{28}$ The utopia that Marx envisaged of the state withering away which was a reversion to the age when China was ruled by $L i$ has not been tempered by the capitalist reforms that have the imperative for China to compete in the world economy. ${ }^{29}$ It is manifest that China intends to be a state where socialist legality is the ideological underpinning but there will be an evolving constitution that develops a legal framework that will augment its economic liberalization. ${ }^{30}$

The Chinese state has maintained the infrastructure of the state bureaucracy governed by the communist doctrine. However, it has inaugurated a market based economy by reversing the doctrine that Marx developed in which the workers exercise the ownership of the means of production for goods. There is a conscious effort to accommodate the economic variables of state capitalism into the industry that the state has developed. The legal framework was

\footnotetext{
${ }^{23}$ Alison Sau-Chu Yeung, Fornication in the Late Qing Legal Reforms: Moral Teachings and Legal Principles, Modern China, Vol. 29, No. 3 (2003), p 297

${ }^{24}$ Derk Bodde and Clarence Morris held that the concept of $f a ̆$ had an association with yi 義 ie "social rightness" . (Law in Imperial China: Exemplified by 190 Ching Dynasty Cases with Historical, Social, and Judicial Commentaries; Philadelphia: University of Pennsylvania Press, (1973) at 14-15.

${ }^{25}$ Yan Fu, Fayi [法意: "The Spirit of the Laws"] (Beijing: The Commercial Press, 1981) 1:7

${ }^{26}$ Weng Li, Philosophical Influences on Contemporary Chinese Law, Indianna International and Comparative Law Review 6 No 2. (1996) at p 331

${ }^{27}$ Socialist legal theory according to Jawitsch prescribes: Complete success in the masses' struggle for their democratic rights and liberties can only be achieved by overcoming monopoly capital's economic and political domination and establishing a state authority that expresses the interests of the working people." L.S. Jawitsch, The General Theory of Law (Moscow, USSR: Progress Publishers, 1981), 160. According to Lenin, "The revolutionary dictatorship of the proletariat is a victory by the proletariat against the bourgeoisie and is uninhibited by a rule of law and is contingent on revolutionary legality. V.I. Lenin, The State and Revolution (New York, NY: International Publishers, 1932 ), 9.

${ }^{28}$ In interpreting the Marxist dogma that law will wither away in a communist state Plamenatz assets that in a communist society there will be no laws because there will be complete harmony and the catalysts for anti-social activity, which are "are injustice and inequality will no longer exist". The criminal incidents will be "virtually unknown" because "motives will be less urgent and frequent, and the offender will be more easily brought to his senses by the need to regain the good opinion of his neighbors." John Plamenatz, Man and Society, 2 vols. (London, UK: Longmans, 1963), 2:374. Cited in Makepeace, Marxist Ideology and Soviet Criminal Law, p 35.

29 "China's capitalist reforms are for more than peaceful co existence between industrialised capitalitalist nations. They entail integration of the Communist party states into the world economy". David S.G Goodman, Communism and Reform in East Asia edited by David S.G. Goodman (RCE Modern RCE Modern East and South East Asia (2015) Routledge, p 3

${ }^{30}$ Su Shaozhi, a leading Dengist and Director of the Marxist -Leninist Mao Zedong Though Institute of Academy of Social Sciences 1982 wrote that " Mao Tse Tung Thought must be distinguished from the thought of Mao himself. It is a theoretical system that is the crystallization of the contributions of our entire party, not only Mao himself .... Some of Mao's own thought is correct and some in error, but the wrong part cannot be included in Mao Tse Tung Thought." Shaozhi, Su, Democratisation and Reform (1988) p 25
} 
amended by the 1982 Constitution when reforms were introduced that no longer guaranteed that the working class exercises leadership through its vanguard, the CCP. However, the committee charged with drafting the 1982 constitution stated "that a legal provision requiring the people to defend and support the party right or wrong was tantamount to yi dang zhi guo, 'using the party to rule the state' ". ${ }^{31}$

The transformation from doctrinaire Marxism to a socialist market economy was premised on the Four Modernisations, post 1977, based on the Deng formula that was designed to develop the sectors of agriculture, industry, science and technology. ${ }^{32}$ Its main objective was to increase the role of the CCP in the reform process and the imperative was capitalisation of the economic structure within a socialist legal framework. ${ }^{33}$ It has succeeded to the extent of promoting a rule of law in which judicial review of administrative action is possible.

The Fourth Modernisation which the Communist party facilitated by developing the legal concepts of făzhì that can be translated as the "rule of law ". ${ }^{34}$ Traditionally, in China there is no such theoretical underpinning in the state's constitution as a rule of law but the PRC has adopted a kernel of rules based on the judicial review of administrative actions and the redress of citizens' grievances in the courts. ${ }^{35}$ The Chinese framework has adopted the concept of yi fa zhi guo which corresponds to "governing the nation in accordance with law" that has been proposed. This notion is blended with jianshe shehui zhuyi fazhi guojia: "building a socialist rule of law state". ${ }^{36}$

The Communist Party's Political- Legal Committees (PLCs) conducts legal studies before a law is enacted and also adopt the mechanisms through which PLCs have conducted supervision over courts. ${ }^{37}$ Xin He states that it is a common belief that " local party committees and governments can effectively influence courts through the PLCs at corresponding levels and all 'major and complex' cases are discussed and ultimately determined by the PLCs". 38 These PLCs are staffed by " senior officials of local party committees, relevant government branches, procuracies and people's congresses. They are usually headed and convened by a senior party member who often serves in the government, such as the head of the police. The director of the courts, however, is usually only an ordinary member of the committees. As the CCP's legal commissions the PLCs function within the internal rules of the party rather than according to any formal legal procedures". ${ }^{39}$ Thus the relationship between the Communist Party and the courts is formalised in the institutional framework of the state, under which the Party has exclusive authority to compel compliance by individual state institutions and by the state as a whole.

Ling Li observes that the courts are empowered "to apply the law but lack the authority to compel compliance with the law by institutions of equal or higher rank in the power hierarchy defined by the CCP". ${ }^{40} \mathrm{Li}$ argues that the impact of this arrangement demonstrates "in fact two sides of the same coin. On the one hand, the CCP assumes a paternalistic role, obliged to provide courts with support to gain access to operational funds and other resources and to lend courts the necessary authority to compel compliance from institutions normally beyond the reach of the courts' own authority. On the other hand, the CCP is able to preserve the supreme authority of decision making in selected and prioritized areas, where it can determine judicial outcomes in an arbitrary fashion to advance its

\footnotetext{
${ }^{31}$ Gao Kai, Guanyu dang de lingdao (On the Leadership of the Party) (Peking University Press, 1982), p. 33.

${ }^{32}$ Zhao Zhiyang, Third Premier of China, rationalised this programme in 1987 at the $13^{\text {th }}$ Party Congress by stating that as China is in the initial stage of socialism, its sole priority should be to develop the productive forces and foster economic growth. Zhao Ziyang, 'Advance along the road of socialism with Chinese characteristics', Beijing Review vol. 30: no. 45 (9-15 November 1987), section V.

${ }^{33}$ Chong-En Bai \& Chang-Tai Hsieh \& Yingyi Qian, "The Return to Capital in China," Brookings Papers on Economic Activity, Economic Studies Program, The Brookings Institution, vol. 37(2006-2), p 61

${ }^{34}$ Hongwen Zhu \&Michael A. Peters, Social governance, education and socialist rule of law in China Educational Philosopy and Theory, Vol 51, no 7, 670-673 https://doi.org/10.1080/00131857.2018.1482643; Also Jaaka Husa, Advanced Introduction to Law and Globalisation, Edward ELGAR,(2018), Chapter 4

${ }^{35}$ Peerenboon postulates the "thin rule of law" that is procedural in nature and with the "Chinese characteristics" which could "develop an alternative version to the western model of the rule of law". Randall Peerenboom, China's Long March Toward Rule of Law, Cambridge University Press (2002) p 65.

36 Titus C. Chen, Recalibrating the Measure of Justice: Beijing's effort to recentralize the judiciary and its mixed results, Journal of Contemporary China, Vol 21, Issue 75, (2012) Pages 499-518 https://doi.org/10.1080/10670564.2011.647437

37 Xin He, Judicial Reform in China. Lessons from Shanghai, International Journal of Law in Context (2007) 203-225 https://doi.org/10.1017/S1744552307003023

${ }^{38} \mathrm{Xin} \mathrm{He}$, Why did they not take on the disputes? Law, power and politics in the decision-making of Chinese courts, International Journal of Law in Context, International Journal of Law in Context, no 3, vol 3 (2007) 203-225 Cambridge University Press DOI: $10.1017 / \mathrm{S} 1744552307003023$

${ }^{39}$ Ibid 223

${ }^{40}$ Ling Li, The Chinese Communist Party and People's Courts: Judicial Dependence in China, The American Journal of Comparative Law, Volume 3, Issue 3, (March 2016) P 37, https://doi.org/10.5131/AJCL.2016.0002
} 
political agenda and goals through both or either of the macro and micro approaches". 41

The Administrative Litigation Law enacted in 1989 has created legal recourse for individuals effected by arbitrary government which was not possible prior to this legislation. Article 1 states " that the purpose of this procedural law is to ensure the correct and prompt handling of administrative cases by the people's courts, protecting the lawful rights and interests of citizens, legal persons and other organizations, and safeguarding and supervising the exercise of administrative powers by administrative organs in accordance with the law". Article 2 "provides a citizen with legal personality and locus standi that their lawful rights and interests have not been infringed and that they have a right to initiate a law suit before a people's court in accordance with this Law". Article 3 stipulates " the people's courts exercise judicial power independently without any interference by any administrative organ, public organization or individual". ${ }^{2}$

This codification of laws and the procedural basis to challenge abuse of power has provided grounds for those who have argued that the PRC has achieved a self contained model of a rule of law. This presupposes that amendments to the statutes of the Chinese Communist Party at its 16th Congress which are part of this same reforming logic which aim to put in place a "socialist democracy" governed by the "law" (yifa zhiguo) and "virtue" (yide zhiguo). The codification of Prime Minister Jiang Zemin's "innovative thought for the 21 st century", whose main thrust was formulated in 2000 in the "theory of the three representatives" (sange daibiao) is, therefore, supposedly to lead gradually towards the rule of law on indigenous lines, the first stage in the process of setting up a democracy, also Chinese-style. ${ }^{43}$

The three ideals are the political reforms that are for the accelerated privatization of the economy: (1) sweeping administrative reform, and attempting to adapt the administrative structure from command planning to the regulation of a market economy; (2) the replacement of a division of powers with a more functionally overlapping, centralized leadership; and (3) elevating the meritocratic recruitment into the national bureaucratic elite. ${ }^{44}$

This has to be set in context of the possibility of challenge in the courts that may review the abuse of power. The two main areas where the substantive law and procedural justice can be evaluated are the property law and environmental justice. The state has enabled the citizens to petition the courts to hear their grievances and to enable it to gain redress by means of public interest litigation.

\section{Public Interest Litigation and Judicial Review}

There are indicators that the rule of law based on judicial review of administration action, participatory justice and redress of grievances is emerging. This is manifested in the property and environmental law where the rights of citizens have been invoked by means of public interest litigation.

\subsection{Property Law}

The Constitution of the PRC provides for the protection of private property. Article 13 provides that "[c]itizens' lawful private property is inviolable. The state, in accordance with law, protects the rights of citizens to private property and to its inheritance." The Chinese Property Law (CPL) enacted in 2007 duplicated the German Civil Code, (Bürgerliches Gesetzbuch or BGB) into its own legislation. ${ }^{45}$ Article 3 of the property statute entitled "Ownership Elements in Socialist Market Economic System" states:

During the primary stage of socialism, the State adheres to the basic economic system wherein public ownership

\footnotetext{
${ }^{41}$ Ibid

42 The Administrative Litigation Law in 1990 was enacted pursuant to Article 41 of the Constitution 1982, and it provides for the right of citizens to make complaints to relevant State organs concerning violations of the law and dereliction of duty and to receive compensation for losses caused by infringement of civic rights. Accordingly the law provides both for review of administrative action and for claims for compensation for damage caused by tortious acts of the administration. There is no provision for "natural justice", nor does the Law provide for the review of an exercise of discretion. The review of the validity of administrative rules is also beyond the scope of review provided for by the Law. Another innovation of the law is set out in Article 71 provides that foreigners, stateless persons and foreign organizations shall have the same litigation rights. http://www.china.org.cn/government/laws/2007-04/16/content_1207336.htm

${ }^{43}$ Ibid p 583

${ }^{44}$ Jiang's 'Three Represents' suggest that the CCP was transcending the working class basis of its mandate and appealing to the 'overwhelming majority of the Chinese people.' Some scholars view this as a radical transformation of the CCP's self-image role from being a 'revolutionary party' committed and empowered to lead the nation towards communism to that of a 'governing party,' which implies a less ideological imperative and a greater sense of being accountable to all citizens of the PRC. Joseph Smith, 'Studying the Three Represents,' China Leadership Monitor 8 (Fall 2003), pp. 2-4; also see Sun Daiyao, Yushi jujin de kexue shehui zhuyi (The Scientific Socialism Keeping up with the Times), pp. $575-587$

${ }^{45}$ Chen, Lei, The New Chinese Property Code: A Giant Step Forward?. Electronic Journal of Comparative Law, Vol. 11, No. 2, September 2007. Available at SSRN: https://ssrn.com/abstract=1286847
} 
is the principal element, and diversified ownership elements develop jointly.

The State solidifies and develops public ownership element, and encourages, supports and guides the development of non-public ownership economic elements.

The State adopts a socialist market economic system, and safeguards the equal legal standing and the development rights of all market subjects." 46

The Property Law consolidates private property but within the framework of a "socialist market economy". There is an equal protection stipulated in the Chinese Property Law and this has to be considered within the context of Equal protection that the Constitution has set out which elevates public property as sacred and inviolable (Article 12) while private property is only inviolable but not sacred (Article 13), leading to the interpretation that public property has more constitutional protection than private property. The equal protection argument is that the statute has made an amendment and its most salient feature has guaranteed private property and public property with "equal protection." 47

Although there is an overlapping jurisdiction as to the priority to be attached to the public property over private rights the citizens can claim and defend their property rights. Leilla Choukroune has suggested that common person is " progressively getting aware of their rights and, encouraged by the dissemination of the concept of "juridicization" (fazhihua), try to believe in the effectiveness of these particular property rights now guaranteed not only by the Constitution, but also by the 2007 Real Rights Law". This confusion has arisen because of the "effective opposability of property rights if neither the Constitution, nor the 2007 law clearly recognizes the right to own land. The later, indeed, does not question two fundamental principles: the public nature of land ownership in urban areas and that of collective ownership in rural areas (article 47)". ${ }^{48}$

However, the Property Law does not underpin the grant of proprietary rights with ownership of land because while "rural residents have ownership of the produce of their land, but not of the land itself, which is collectively owned". 49 There are further dilemmas in constructing a land law theory where private land cannot be freely alienated or sold by private landlords. This is because the state is the ultimate landlord and exercises a freehold interest in land. This can be inferred by the right of expropriation (zhengshou) provided to the state under the Article 42) when the public interest (gonggongliyi) is overriding in appropriating land if reasonable compensation (xiangyingbuchang) is awarded. There is no clear separation between the "civil and administrative law or national and local authorities" which means that the "administrative recourses against these illegal expropriations and unfair compensations are extremely limited" in the machinery of justice and review " is still very much linked to the interest of the local Party-State". ${ }^{50}$

There is a recognition that despite law based on traditional values of recognising public ownership of land the registration of interests in land will be necessary if these laws have effect, and then they will give rise to proprietary rights. The collective ownership is enshrined in the constitution but the increasing consciousness of the public will lead to public interest litigation and challenges that are heard by judicial review of rights in land. This will test the adjudicators and judges will have to decide the basis for the rights have been infringed by the state.

\subsection{Environmental Law}

The Environmental Protection Law enacted in April 2014 is aimed to increase the public participation under Chapter 5 and ability to process application to the local governments in dealing with aggrieved citizens. Article 58 defines the 'authorities or relevant organizations' that are allowed to file a Public Interest Environmental Litigation (PIEL) submission. This is any NGO which, being duly registered with a prescribed civil affairs authority, has been engaged in environmental protection activities of public interest for at least five consecutive years and has no record of violating laws. ${ }^{51}$ The provisions include the obligation to "protect the public health" as a general

\footnotetext{
${ }^{46}$ Property Law of the PRC http://www.china.org.cn/china/LegislationsForm2001-2010/2011-02/11/content_21897791.htm

47 See Liming Wang, Wuquanfa Xianming Tese Zaiyu Queli Pingdeng Baohu Yuanze [The Distinct Characteristic of the Chinese Property Law Is Establishing the Equal Protection Principle] (Jan. 16, 2007) http://news.sina.com.cn/c/1/2007-01-16/184412054017.shtml. See also Lian Zhang \& Hao Wang, Zhongguo Tese Shehui Zhuyi Tudi Wuquan Zhidu De Jiangou Yu Fazhan [The Construction and Development of a Land Use and Property System with Chinese Socialistic Characteristics] (Jan. 26, 2009), http://www.civillaw.com.cn/article/default.asp?id=42867

${ }^{48}$ Leilla Choukroune, The Language of Rights and the Politics of Law: Perspectives on China's Last Legal Ditch Struggle, International Journal for the Semiotics of Law - Revue internationale de Sémiotique juridique volume 29, (2016) p 779

49 Ibid

50 Ibid

51 See PENG Bo and MAO Lei, '[The General Office of the Standing Committee of National People's Congress held a Press Conference] People's Daily (24 April 2014) Chinese Journal of Environmental Law 1, 2 (2017). 10.1163/24686042-12340013
} 
principle (art. 1), and has broadened the locus standi for environmental public interest litigation (art. 58). There has been procedural reforms for civil action under Article 9 of the General Rules of the Civil Law, enacted in 2017, stating that "[a]ny civil activity conducted by civil subjects shall be conducive to saving resources and protecting the ecological environment."

The PIEL remedies include any 'conduct that pollutes the environment' as in the CPL but also against conduct which 'causes ecological damage. ${ }^{52}$ Following this reform, the Supreme People's Court (SPC) adopted several 'judicial interpretations' which clarify the modalities of PIEL, in particular with regard to standing and procedural arrangements pertaining to raising a cause of action. ${ }^{53}$ The NGOs authorised to initiate a PIEL include Government-organised Non- Governmental Organisations (GONGOs) but also more independent 'grass- roots NGOs'. However, the stipulation that an NGO should be duly registered with local authorities precludes as many as $60 \%$ of environmental associations, including all foreign NGOs. ${ }^{54}$

Zhang Qing and Benoit Mayer argue that "the existing legal framework is yet to define specific responsibilities" concerning the liability and it "neither defines, nor even acknowledges the role" that participants in EPIL should contribute in the enforcement of Environmental Impact Statements. In some instances the courts have ensured that the "remedies should be controlled jointly by NGO plaintiffs, relevant environmental agencies and the community in general", and that it was " likely that this practice will progressively extend to other cases as more PIELs reach the remedy phase". 55

The public interest litigation assists in the environmental protection cases that have been judicially reviewed. In May 2018, the Fourth Intermediate People's Court of Beijing held a public trial, with a grand collegial judicial panel in the first public interest litigation concerning air pollution in Beijing, in which a steel structure engineering company was prosecuted for emitting unprocessed volatile organic carbon during an industrial procedure. In People's Procuratorate of Beijing (4th division) v. Beijing Duocai Lianyi Int. Ltd., Co ${ }^{56}$ the court appointed four jurors by invoking the People's Assessors Law, 2018 which under Section 1 is intended to increase "peoples participation" and issues findings by the people's assessor, or juror, "equal weight as those of the judges regarding questions of facts".

Under the Constitutional Amendment of 2018 to the Chinese Constitution Article 46 has been devised to enable the protection of the environment to the duties and powers of the State Council. Article 89 reads: "(6) to direct and administer economic affairs and urban and rural development, as well as the building of an ecological civilization" (emphasis added). This implies an increased emphasis of the PRC to protect the institutions and economic infrastructure of the state.

The Chinese law has developed into a framework of collective ownership in which there is an increasing space for public interest litigation. The legal system is based on the framework of a socialist rule of law and the substantive law has been supported by the Administration Litigation Law that is increasingly facilitating challenge by the judicial review of administrative action. The property law is based on a private purchase but it does retain the right of compulsory acquisition for the state. The environmental law offers protection of the environment whereby the potential exists for the participation of ordinary citizens to be involved in decision making.

\section{Independent Judiciary and Oversight of Legislation}

The CCP is the only regulated and functioning party in the PRC. ${ }^{57}$ Its position cannot be challenged in the Chinese

52 The EPL 2014, Article 58.1.

${ }^{53}$ See in particular ' [The Interpretation of the Supreme People's Court on Several Issues Concerning the Application of Law in Environmental Civil Public Interest Litigation Cases] which was issued in January 2015 and provided a guideline for trial of PIEL as well as the implementation of Article 58. See also, ' [Interpretation of the Supreme People's Court on the Application of the Civil Procedure Law of the People's Republic of China] (effective on February 2015). The SPC's judicial interpretations have binding force by virtue of the application of article 104 of the Legislation Law (revised 2015)

${ }^{54}$ See CAO Mingde, [An Analysis on the Policy and the Law for the Existence and the Development of the Chinese Environmental NGO] (2013) 3 Tsinghua Journal of Rule of Law 17, 19, 26. Even so, the final version of EPL 2014 is much broader than the initial drafts.

55 Richard Zhang Qing and Benoit Mayer, Public Interest Environmental Litigation in China Chinese Journal of Environmental Law 1 (2017) p 227

56 30-7-17 http://www.spp.gov.cn/dfjcdt/201707/t20170730_197128.shtml.

57 The CONSTITUTION OF THE COMMUNIST PARTY OF CHINA (Revised and adopted at the 19th National Congress of the Communist Party of China on October 24, 2017 General Program) states in its preamble " The Communist Party of China is the vanguard of the Chinese working class, the Chinese people, and the Chinese nation. It is the leadership core for the cause of socialism with Chinese characteristics and represents the developmental demands of China's advanced productive forces, the orientation for China's advanced culture, and the fundamental interests of the greatest possible majority of the Chinese people. The Party's highest ideal and ultimate goal is the realization of communism". xinhuanet.com//emglish/download/Constitution_of_the_Communist_Party_of_China_pdf 
constitutional system and the power is vested by the appointment of a Standing Committee of the National People's Congress (NPC) with the right to interpret the Constitution of the Republic of China $\S 67(1)$ ). This allows an overlap with the legislative powers which has the potential to produce tensions between the administrative errors by the state and judicial review by the courts.

The CCP has full control over the state apparatus since it began the period of being the sole legally constituted party under Chairman Mao's premiership. The Chinese academic Zhu Suli has observed:

Despite the many political differences between the CCP and its former arch-rival, the Nationalist Party (known as the Guomindang or GMD) and despite the fact that the CCP never used the GMD's often deployed concept of the party-state, "in practice, the CCP inherited the political tradition, initiated by Sun Yat-sen5 and pursued by the GMD, comprised of a party construction of the state, "party rule of the state, "and party above the state. "Indeed, eventually, the CCP's influence over society and the machinery of the state would far exceed that achieved by the GMD. ${ }^{58}$

Zhu infers that owing to the political and the constitutional development in China the legal hierarchy has been subsumed in the framework of the CCP. He argues that in contemporary China nearly every political force has either been "integrated into the CCP", or, in the case of those who opposed the revolution has been purged during the Cultural Revolution (1966-1976), and then "denied political expression." The CCP is a seminal part of the governance structure of the Chinese nation and it has a central role which is embodied in the fabric of China's evolving constitution and institutional powers.

The NPC Standing Committee has an overriding authority by its constitutional over- sight provisions and "for the courts to play a more active role in ensuring full adherence to constitutional norms" would need to overcome in "addition to the ideological and structural barriers to judicial review " they must also overcome established precedence and the "NPC's desire to protect its own constitutional prerogatives, the courts 'own lack of independence, and even formal statements by the Supreme People's Court (SPC) renouncing constitutional interpretive authority". 59

The PRC has not developed a Constitutional Court as part of the legal order that could adjudicate in challenges to the law that is framed against the provisions of the constitution. ${ }^{60}$ The adjudication of legislation in accordance with the constitutional norms is, therefore, absent and this means that concepts such as the legal umbrella under which the CCP operates and delegates power cannot be challenged. There is no institutional mechanism for legitimizing the expression of political power as constituted within the framework of the Chinese Constitution which presently vests only in the NPC. There is no constitutional court that can hear a challenge to its proposed laws that may not be in accordance with the constitutional preamble of the PRC Constitution. ${ }^{61}$

If the CCP were to adopt a Constitutional Court it would be able to incorporate another aspect of governance within the organ of the constitution that will be able to validate its legislative power. The rulings of the court would be based on the normative provisions of Chinese constitutionalism, including the vanguard status of the CCP and the principles under which its organisation must function.

Backer observes:

The distinction is that the constitutional court that is framed on these principle will institutionalize the actual positions of the CCP as the party in power within a constitutionalist system. Justifying the power of the CPP would fold the current oversight role of the CCP within the constitutional framework of the current constitution, provide an institutional framework for the assertion of the CCP's authority to determine political values, create a mechanism for transparent and regularized political expression, and institutionalize relations between the state apparatus and the CCP as party in power. At the same time, justifying the political role of the CCP at the

\footnotetext{
58 Zhu Suli, Political Parties in China's Judiciary, 17 Duke Journal of Comparative and International Law (2007) 533-538

59 Thomas E. Kellogg, Constitutionalism with Chinese characteristics? Constitutional development and civil litigation in China, International Journal of Constitutional Law, Volume 7, Issue 2, April 2009, Pages 215-246, at 217 https://doi.org/10.1093/icon/mop001

${ }^{60}$ Hans Kelsen who framed the Constitutional Court observed: "There was sovereignty of Parliament and no court can question its validity or question an Act in Parliament, which is the supreme law of the land. Before the constitution of 1920 the power of the courts to pass on the legality and hence of the constitutionality of a decision was not restricted ". Hans Kelsen, Judicial Review of Legislation: A Comparative Study of the Austrian and American Constitution, 4 JOURNAL OF LAW \& POLITICS 183 (1942) at p185

${ }^{61}$ Freejohn's argues that a Constitutional Court" offers a necessary protection from abuses of power, internal and external, individual and institutional. It is not the designation of the institution as a juridical forum as that would be the appellate courts function in a country's jurisdiction" John E. Ferejohn, Constitutional Review in the Global Context, 6 Legislation and Public Policy 49 (Dec. 2002 ). pp 52-54
} 
constitutional level would not necessarily limit the CCP's political role generally as the party in power. ${ }^{62}$

Professor Hu Jinquang addresses the critical issue of the nature of judicial review and distinguishes between it and constitutional review. He focuses on the "centrality of economics as foundational framework for state organization and the central element of state power over the economy" within the framework of the Marxist Leninist emphasis on economics as the infrastructure of the political and social order. ${ }^{63} \mathrm{Hu}$ observes that "it was a necessary focus of state organs on the executive power, and in a rule of law context, on administrative law". ${ }^{64}$

The CCP has rejected the institution of a constitutional court at the 10th NPC in 2004 by asserting the sovereign role of the Communist party as the sole representative of the Chinese people in the Central Politburu. ${ }^{65}$ The NPC has constitutional oversight which is restricted to equal or inferior organs and does not include the CCP. The constitution provides for the Communist leadership over the state and, secondly, it expressly provides that those under the supervision of the NPC does not include the Communist Party.

Zhang Chunsheng, a member of the NPC Law Committee formulated the reasons for not constituting a Constitutional Court because the framework in China was radically different from that adopted in the west.

His reason was that "the division of three powers - constitutional, legislative and executive - so their constitutional courts have the right to supervise the executive and legislative bodies." However, on the mainland, only the NPC and its Standing Committee had the legal status to supervise the implementation of the constitution. It means that the NPC "cannot put in place a constitutional court or supreme court to supervise the implementation of the law" and it has rejected the foundation of a Constitutional Court in China. ${ }^{66}$

There are three proponents of constitutional theory in China which advocate different aspects of Chinese evolution to the constitutional state. There are those who espouse the orthodox view and reject the possibility of a separation of powers in China between the executive and the judiciary because of the omnipresent rule of the CCP, the NPC and its Standing Committee. The diametrically opposite perspective is based on the view that the scheme does not allow the judicial organs to function independently and the executive does not provide the freedom of maneuver to judges to operate with independence in interpreting the law. ${ }^{67}$

Professor Yan Lin takes the view that the various organs of the state are autonomous because there are alternative routes which provide the scope for judges to interpret the law. He argues that the "Constitution does, to some extent, define the relationship between the judiciary and the executive. First, in order to ensure judiciary independence, it prohibits the executive branch from intervening into adjudicatory activities. (Article 126) Second, it also demands that the court, the procuratorate, and the police department, while handling criminal cases, ". . divide their functions, each taking responsibility for its own work, and they shall coordinate their efforts and check each other to ensure the correct and effective enforcement of the law." (Article 135) Nevertheless, the Constitution does not openly authorize the courts to affirmatively supervise the executive on law enforcement affairs by reviewing administrative cases".68

Ling Li argues that the political reforms in China since 1980s have not severed the power of the Party from the state but instead have created an increasingly "institutionalized dual normative system that is more complex,

${ }^{62}$ T Larry Catá Backer Communist Party and the Constitutional State: A Theory of Constitutionalism and the Party-State, 16,1 Journal of Chinese and Comparative Law (2009) p 68.

${ }^{63} \mathrm{Hu}$ Jinguang, Evolution and Challenge of Review of Public Authority in China, Presentation Conference on Constitutionalism in China in the Past 100 Years and Its Future (In TL Catá Backer Communist Party and the Constitutional State, p 91)

${ }^{64}$ Ibid

${ }^{65}$ Article 22 The Political Bureau, the Standing Committee of the Political Bureau and the General Secretary of the Central Committee of the Party are elected by the Central Committee in plenary session. The General Secretary of

the Central Committee must be a member of the Standing Committee of the Political Bureau.

${ }^{66}$ Harry Doran, Beijing Rules Out Constitutional Court (for human rights and private property) - Decision Increases Fears that NPC Rights Amendment May be Little More than Window Dressing, S. CHINA MORNING 2011] RESOLVING CONSTITUTIONAL DISPUTES IN CHINA; NPCSC Chairman Wu Bangguo explicitly rejected a proposal to incorporate a system of judicial review into the Constitution. Huang Jie, The Urgent Task of Establishing the Judicial Review System, in CONSTITUTIONALISM AND CHINA (Li Buyun ed., 2006) Beijing: Falu Chubanshe. at $\mathrm{p} 245$

${ }^{67}$ See William C. Jones, The Constitution of the People's Republic of China, 63 Wash. U. L. Quart. 707, 712 (1985); Donald Clark, Puzzling Observations in Chinese Law: When Is a Riddle Just a Mistake?, in Understanding China's Legal System 105 (C. Stephen Hsu ed., 2003). Although realizing the lack of judicial enforcement is a big setback for China, some still claim that "an unenforced constitution may still be useful.” See Zhang Qianfan, A Constitution without Constitutionalism? The Paths of Constitutional Developments in China, 8 Int'1 J. Const. L. 950 (2010).

68 Yan Lin, Constitutional Evolution through legislation: The quiet transformation of China's Constitution. International Journal of Constitutional Law, Vol 13.1 (2015) at p 67 
compared with the previous fused system" that can be harnessed for amendments and is liable for varying interpretations "including to that of the 'Party-state constitutionalism', which applies the "'rule of law" as compatible with the rule of the Party'." It can be formulated as a "dual normative system" to interpret the constitution "four components: 1) structural integration of the Party and the state; 2) reserved delegation of authority to the state; 3) bifurcation of state decision-making processes and 4) cohabitation of two normative systems: one of the Party and one of the state." 69

This makes the process of the courts in adjudicating disputes more onerous because the framework of judicial review is limited to the oversight of the actions of the state administration. Judicial review is meant to serve as a mechanism for the self-discipline of state organs within the limits of their functional role within Chinese constitutionalism. However, this role is restricted by the authority of state institutions and the limitation accorded to the judicial power and co-extensive with that power is the need to ensure its proper use. The sovereign power, which as the political power of the nation is greater than that accorded to state organs under the Constitution. The $\mathrm{CCP}$, as the vanguard party is accorded a constitutional role beyond that of the authority of the state by the instrument of the NPC and its Standing Committee.

\section{Role of the Party and Extension of Judicial Branch}

This development of judicial review has been restricted by the powers of the CCP which acts as a parental institution. The reforms initiated by the present Chairman of the CCP and President Xi Jinping who since assuming office in 2013 centralised the power of the CCP. This has led to the amendments in the Chinese constitution in 2018. Xi has initiated the assimilation of the Communist ideology into the constitution by adopting the "Xi Jinping Thought on Socialism with Chinese Characteristics for a New Era", validitating it as an additional guiding principle to "Marxism-Leninism, Mao Zedong Thought, Deng Xiaoping Theory, the Theory of Three Represents, and the Scientific Outlook on Development". ${ }^{70}$ The indoctrination of the "Xi Thought", that is in the preamble of the 2018 constitution is included in the educational institutions as part of their curriculum. ${ }^{71}$

The Chinese Constitution can be interpreted as an enabling document that has been amended so many times as the test for "barometers of the state's policies and values that reflect the current social condition". ${ }^{72}$ It is generally accepted that the courts have not prioritsed the "constitutional interpretation for the purpose of constitutional rights protection". This is because of the perspective that "most government officials" in China's constitutional structure deem that " the NPC Standing Committee has exclusive authority" in the interpretation of legislation. ${ }^{73}$ The NPC adopted an amendment to the PRC Constitution in March 2018 that has transformed the role of the CCP by integrating the role of the Communist Party in the government of the state. The current text of article 1 goes even further than the 1975 and 1978 constitutions by terming the leadership of the CCP as the "defining feature of socialism with Chinese characteristics". It establishes one-party rule as an end in itself, as opposed to a means for achieving some distant goal.

There has been a constitutional amendment to 21 articles numbered from 32 to 52 (continuation of the sequence from Article 31 of the previous constitutional amendment). ${ }^{74}$ In this new framework there are significant provisions and Article 32 replaces, in the seventh paragraph in the Preamble to the Constitution with the text "improve the socialist legal system" to "improve the socialist rule of law".

\footnotetext{
${ }^{69} \mathrm{Ling} \mathrm{Li}$, "Rule of law" in a Party-state - A conceptual interpretive framework of the constitutional reality of China. Asian Journal of Law and Society, Vol 2 Issue 1(2015) p 93 https://doi.org/10.1017/als.2014.21

${ }^{70}$ Resolution of the 19th National Congress of the Communist Party of China on the Revised Constitution of the Communist Party of China, China Legal Information Centre, October 24, 2017http://english.legalinfo.gov.cn/2018-12/14/content_37409665.htm

${ }^{71}$ Michael Adrian Peters, The Chinese Dream: Xi Jinping thought on Socialism with Chinese characteristics for a new era, Educational Philosophy and Theory (2017) 49(14) p 1

72 Ann Kent, Waiting for Rights: China's Human Rights and China's Constitutions,1949 - 198913 HUMAN RIGHTS QUARTERLY. 170, $182(1991)$.

${ }^{73}$ Lo, P. Y. and Chen, Albert H. Y., The Judicial Perspective of 'Separation of Powers' in the Hong Kong Special Administrative Region of the People's Republic of China (October 5, 2018). (2018) Journal of International and Comparative Law (JICL), Vol 5(2), 337-362, at 337 Available at SSRN: https://ssrn.com/abstract $=3267096$

${ }^{74}$ (Zhonghua Renmin Gongheguo Xianfa Xiuzheng An [PRC Constitutional Amendment] (adopted by the NPC on Mar. 11, 2018) (2018 Amendment), NPC website; Changhao Wei, Translation: 2018 Amendment to the P.R.C. Constitution, NPC OBSERVER (Mar. 11, 2018).) https://npcobserver.com/2018/03/11/translation-2018-amendment-to-the-p-r-c-constitution/
} 
This will have an impact on the political legal system devised for the training of legal personnel by the Communist Party. ${ }^{75}$ Article 36 inserts a new sentence in paragraph 2 of Article 1 of the Constitution after " $[\mathrm{t}]$ he socialist system is the basic system of the People's Republic of China" to read "The defining feature of socialism with Chinese characteristics is the leadership of the Communist Party of China." Article 37 grants the new supervision organ (supervisory commissions) constitutional status, by adding the phrase "supervision organ" to paragraph 3 of article 3 of the Constitution. It states: "All administrative organs, supervision organs, adjudicatory organs and procuratorial organs of the State are created by the people's congresses to which they are responsible and by which they are supervised.

There is an important extension by Article 45 which repeals the serving term for the President and Vice President of the PRC set down in the 1982 Constitution. Under Article 79 the President and Vice President could not serve more than two consecutive five-year terms. ${ }^{76}$ Article 47 has the effect of decentralising the power by dividing cities into districts and the power to make local regulations by adding a new paragraph 2 of Article 100 of the Constitution, which reads as follows:

"The people's congresses of cities divided into districts and their standing committees may adopt local regulations in accordance with the provisions of law, provided that they do not contravene the Constitution, laws, administrative regulations, and the local regulations of the corresponding provinces or autonomous regions, and they shall take effect after being reported to and approved by the standing committees of the people's congresses of the corresponding provinces or autonomous regions."

There is another important change under Article 52 which frames a new section on the creation of State Supervisory Commissions by section 7. Under chapter III of the Constitution, "The CCP's Central Committee has established a series of Supervising Commissions as an oversight mechanism to oversee local commissions and answer to the NPC and the Standing Committee".

The inauguration of the State Supervisory Commissions empowers the Party's leadership which offers the very basis of socialism with Chinese characteristics. These are defined as follows:

"Supervisory Commission to the Constitution represents a big adjustment of the political institution 's powers and relation among different bodies of the Chinese state. The revision of the Constitution is of historical significance for ensuring the prosperity and lasting security of both the Party and the country (including the Chinese lawmakers); and in fact the structural reform plan is intended to strengthen the Party's leadership, improve the efficiency of state governance and overcome the institutional obstacles to reform. The change in the fundamental laws of Chinese are the basis for further advancements and reforms and they were deemed necessary for developing a more sophisticated economy." 77

It is further postulated that the Supervision Commissions in the amended constitution allows this new apparatus extraordinary power over the fate of China's bureaucracy by a centralised organ of the state. The powers vested in them are in the form of four new articles (123-127) that refer to their establishment "to oversee anticorruption efforts, supported by local supervisory commissions at various levels". The decision to "establish the National Supervision Committee system (the SC system) has transformed China's previous dual-track anti-corruption system into a single anti-corruption agency model in the three experimental locations. Merging with the party's Discipline Inspection Committees (DICs), the SCs have absorbed the anti-corruption force of the procuratorates and have become the only anti-corruption agency."

The effect of this innovation is that "party center" has been strengthened and it has taken decisive steps to maintain its authority "in the new model, rather than relinquishing control or necessarily promoting the rule of law." ${ }^{78}$ This reform has set in motion an operating system that entrenches the concepts of dictatorship of the party with its

\footnotetext{
${ }^{75}$ A study shows "legal education in China is embedded in a political-legal system, and Chinese Communist Party domination infuses many aspects of legal education, including the important system of political-legal colleges". Ling Zhou and Michael Palmer, Changing legal education in China- the political legal system, academic study and professionalism, Key Directions in Legal Education: National and International Perspectives, edited by Emma Jones and Fiona Cowie, (2020) Taylor and Francis, p 17

${ }^{76}$ Liu Songshan had called the abolition of lifetime appointments for top state leaders "a historic reform of China's political system and a fundamental change whose positive impact and progressive significance cannot be overstated." Liu Songshan, "Baer xianfa de jingshen zuoyong yu juxian" (The Spirit, Function, and Limitations of the 1982 Constitution), Journal of East China University of Political Science and Law, 2012, no. 6, p. 70 .

${ }^{77}$ Xugang Yu, Mario Tettamanti, Cristiano Rizzi, China's Central Reform in a New Era. Their impact on Chinese Foreign Direct Investments and RMB Internationalization. World Scientific Publishing Co Ltd (Singapore) (2020) 65-66

78 Jinting Deng, The National Supervision Commission: A new Anti-Corruption Model in China, International Journal of Law, Crime and Justice viol 52, (2018) p 58. sciencedirect.com/science/article/abs/pii/si756061617300848
} 
origins in the 'revolutionary' legality of 1949 and it removes the distinction between the party and the state. However, the CCP has granted a measure of judicial review powers by empowering the judiciary to be autonomous and to work independently and without coercion from the party.

\section{Judges Law and Dispensation of Justice}

The Constitutional amendment of 2018 is has been instrumental in instituting reforms that impact on the judiciary and there is more uniformity in the system in which the CCP 's central or provincial committees. This reflects in the appointment of judges in the new dispensation of the PRC " Opinion of the Supreme Peoples Court on Comprehensive Deepening the Reform of the Peoples Court fourth five year reform session (2014 -2018). This emphasised the necessity for " independent judicial reforms to progress judicial efficiency and fairness." ${ }^{179}$ The most significant reforms of the Peoples Courts is the establishment of a "judicial system separated from administrative division through making circuit courts of the Supreme Peoples Court"; the establishment of "intellectual property courts"; and the "reform of the environmental court jurisdiction system". ${ }^{80}$

The outcome is the creation of an "open platform for the trial process, regularisation, and professionalism of court personnel through reforming the court management system method of selection of judges; judicial performance assessment method, salary scheme in enduring exercise of judicial authority of peoples courts is carried out independently and consistent with the law by reforming and improving unified management of court personnel below the provincial level" ${ }^{81}$ The reforms have been accomplished by the PRC taking the initiative by enacting the Judges Law in order to progress judicial reform. This is to attain judicial reform as well as enhancing "judicial quality, credibility and efficiency. ${ }^{82}$

The judiciary is required to complete "the new national unified qualification exam for legal professionals". ${ }^{83}$ This is intended to improve their ability to judicially review cases because "judges will now sign their own judgments, cutting through the chains of command, a scheme that is already being successfully piloted. Reform of judicial committees should give judges greater authority and status in the court itself. As it stands, a Chinese judge is often just one player in a vast and complex set of administrators and officials and has a role not dissimilar to a clerk in an English court". ${ }^{84}$ There are other reforms that are for increasing judicial independence because there is "to be greater delineation between judges and non-judges (the court administrators, the cadres, the officials) so that there is a clearer understanding about who hears and decides on cases. The number of judges overall is to be drastically reduced. China currently has an estimated 200,000 judges. The reforms propose to cut that number considerably, to around $80,000^{\prime \prime} .85$

The new circuit courts that for hearing petitions in the rural communities "have been defined as being "reminiscent of the first assizes in England in the 12th century, which assisted in bestowing justice at a local level, but also acted as a means of ensuring national laws - as opposed to common local ones - were properly understood and implemented". ${ }^{86}$

This process has also raised the issue of the Chinese judiciary that is more interactive with international jurists through " negotiating the (draft) Convention on the Recognition and Enforcement of Foreign Judgments at the Hague Conference on Private International Law, the Arrangement on Reciprocal Recognition and Enforcement of Judgments in Civil and Commercial Matters between China and Hong Kong" and the "questions it raises for outside observers is-what vision does it convey of the Chinese judge? What rights and responsibilities does a Chinese judge have under this law? Will this law, if enacted in its current form, encourage competent people to remain in the judicial system and promising young people to enter it?" 87

\footnotetext{
${ }^{79}$ MS Islam, Judicial Reforms in China: The Way of Strengthening the Judicial Independence, Diponegoro Law Review, Issue 5 (1) (2020) 1 -

18https://www.researchgate.net/publication/341068118_JUDICIAL_REFORMS_IN_CHINA_THE_WAY_OF_STRENGTHENING_THE_ JUDICIAL_INDEPENDENCE

${ }^{80}$ Ibid Page 8

${ }^{81}$ Ibid Page 9

${ }^{82}$ The PRC Judges Law of the Peoples Republic of China, Amended on 23 April 2019. http://www.npc.gov.cn/zgrdw/npc/xinwen/201904/23/content_2086082.htm

${ }_{83}$ Wang Aili, China Focus: China Adopts Revised Laws on Judges 23 April 2019, xinhuanet.com/english/2019/04/23c_138002581.htm

${ }^{84}$ Pollu Bartsford, China's judicial reforms are no revolution. International Bar Association. https://www.ibanet.org/article/846C87E8-A4AA4A88-A7FC-E6FC136C2FCA

${ }^{85} \mathrm{Ibid}$

${ }^{86}$ Ibid

${ }^{87}$ Supreme Peoples Court Monitor, what-does-chinas-judges-law-draft-mean/
} 
The judicial review is based on separating the judicial organ from the political executive and its impact has been commented on by Y Wang who states that the judicial " reforms have, at least in the short term, increased the autonomy of judges by enabling them to render judgements without prior approval from higher-ranking judges and by limiting the use of adjudication committees. These changes have not only reduced higher-ranking judges' influence over most cases, but also weakened the key mechanisms that powerful outsiders use to interfere in judicial matters." ${ }^{18}$

Wang argues further that the judicial reforms exist in parallel to the "seemly impenetrable local embeddedness" in China's "monolithic nature" and "if not for the sweeping anti-corruption campaign and the subsequent centralization of political power, many reform measures will likely be disregarded in practice, especially in more rural and underdeveloped regions". However, in the progress of recent reforms " the enhancement of the courts' power and autonomy does not seem to depend on the liberalization of the political system, but rather on the power consolidation within the already authoritarian government". ${ }^{89}$

The Judges law is a genuine reform of the legal framework in the PRC and provides the basis for judicial review of administrative action. It has infused a training scheme for judges and provided an independent function which is separate from the legal political committees of the NPC. The dispensation that the judges have been allotted since the latest amendment to the law in 2019 is a platform for an autonomous judiciary rather than as delegated members of the political hierarchy. This is an attempt at regenerating a system by professionalism and responsible functioning of the judicial authority in China.

\section{Conclusion}

The question in this essay was whether the PRC has been successful in implementing the judicial review process within the Chinese constitutional framework and to provide judicial administration that also has an access to justice? In a state with a separation of powers the judiciary carries an independent review of administrative bodies, application of impartiality in the interpretation of legislation; redress of grievances, and a check on the powers of the executive.

In the PRC the state is a powerful entity under the control of the Communist party and the analysis has to consider the historical development of institutions that enforce a rule of law and the recent legislation that has led to judicial activism. The framework of a state based on parental control law provides oversight mechanisms for the state and the applied language used for 'law' related concepts that exist in the Chinese intellectual tradition of $l i$ and $f a$. They are part of the civilisational history of China that has constructed the platform for the Communist Party. The executive power is vested in the National Peoples Congress and the state organs which do not distinguish between the national power and the political power are entrusted under the Communist Party leadership. The state power has become bureaucratised within settled institutions which is embodied in the overriding institution of the executive and its legislative authority.

The amendments to China's constitution in 2018 has increased the public interest litigation and an Administrative law framework law has developed. This provides an emerging basis for judicial review and redress of grievances and the Judges Law 2019 has introduced professionalism and efficiency as the new benchmarks for legal officers. The socialist rule of law and centralisation of power by the Communist Party and an originating judicial review in the courts are not mutually exclusive The framework has the potential to provide redress of grievance in the courts and to also override any fetters imposed by the executive on the machinery of justice.

\section{Copyrights}

Copyright for this article is retained by the author(s), with first publication rights granted to the journal.

This is an open-access article distributed under the terms and conditions of the Creative Commons Attribution license (http://creativecommons.org/licenses/by/4.0/).

\footnotetext{
https://supremepeoplescourtmonitor.com/2019/01/26/what-does-chinas-judges-law-draft-mean/

88 Yueduan Wang, OVERCOMING EMBEDDEDNESS: HOW CHINA'S JUDICIAL ACCOUNTABILITY REFORMS MAKE ITS JUDGES MORE AUTONOMOUS, Fordham International Law Journal, Vol 43:4 (2020) 737-766 https://www.fordhamilj.org/volume-43issue-3/2020/3/5/overcoming-embeddedness-how-chinas-judicial-accountability-reforms-make-its-judges-more-autonomous

${ }^{89}$ Ibid p 765
} 